\title{
The accumulation of heavy metals and cytometric characteristics features of red blood cells in different ages of carp fish from Zaporozhian Reservoir
}

\author{
Fedonenko Olena, Yesipova Nataliia, SharamokTetyana*
}

Oles Honchar Dnipropetrovsk National University, Ukraine

Faculty of Biology, Ecology and Medicine, Department of General Biology and Water Bioresources
P.M.B. 49050, Dnipropetrovsk, Ukraine

Corresponding Email: sharamok@i.ua

Keywords: Zaporozhian Reservoir, heavy metals, red blood cells, roach, prussian carp

\begin{abstract}
The research was held in terms of Zaporozhian Reservoir (Ukraine) from 2014 till 2015 year. It was established that prussian carp (Carassius gibelio Bloch, 1782) and roach (Rutilus rutilus Linnaeus, 1758) underyearlings accumulate essential elements more extensively, especially zinc, comparing to adults ones. The species characteristic of heavy metals accumulation in the carp fish body was observed. The intensity level of erythropoiesis occurrence was higher in young fish of both species of carp fish. The specific features of cytometric characteristics of fish erythrocytes were identified: the relative amount of mature red blood cells prevailed in roach, and the area of mature red blood cells was significantly higher in prussian carp. In addition, in the young roach among immature forms of red blood cells significantly higher percentage of polychromatophil normoblasts was revealed.
\end{abstract}

\section{INTRODUCTION}

Nowadays the global anthropogenic factors have been changing the habitat of fish [1].

Among the anthropogenic factors that influence on aquatic organisms, the greatest danger is posed by industrial effluents containing heavy metals. The toxicity of heavy metals is closely linked to their physical and chemical properties. They are characterized by high biological activity, the ability to accumulate in tissues and organs of living organisms $[2,3]$.

The system of fish blood is a convenient experimental model to identify the environmental state of aquatic environment. With an organisms' adaptation to extreme situations blood, being a self-regulating system, acts as a sensitive objective indicator of the internal and external environment state $[4-6]$.

It was established that changes in hematological parameters depend on the pollutants concentration and duration of exposure, the type of fish, their age and condition of health [7 - 10].

A lot of researchers use cytometric indications red and white fish blood cells as an indicator of the water contamination degree [11 - 14].

The accumulated material revealed a number of the regularities in changes of cytometric parameters in different species of fish peripheral blood erythrocytes with the influence of heavy metals [15], hypoxia [16, 17], and technological conditions of artificial cultivation [18], etc. But in most cases fish of older age groups were used for researching, beginning with the two-year old species [19]. Also, there is almost no data on characteristics of structural and functional state of erythroid cells in underyearlings.

Meanwhile, the fish organism is the most sensitive to anthropogenic factors and more suitable as bioindicators environment in the early stages of growth. Also, cytometric researches of fish red blood cells may be useful to determine the condition of fish health and development of clinical pathology criteria [20-22].

The aim of research was to identify the features of heavy metals accumulation and cytometric and morphological and physiological characteristics of underyearlings and adult age groups of prussian carp (Carassius gibelio Bloch, 1782) and roach (Rutilus rutilus Linnaeus, 1758) erythrocytes - the most common carp fish in Zaporozhian Reservoir. 


\section{MATERIALS AND METHODS}

Researches were conducted in Zaporozhian Reservoir - the multi-purpose reservoir during 2014-2015. The reservoir is located in the South-west of Ukraine, in the territory of the agroindustrial zones and been under strong anthropogenic influence. According to the results of longterm monitoring researches the bar area of high heavy metals concentration, salinity and eutrophication were found in the reservoir waters $[23 ; 24]$. Samples of fish were collected in the lower part of the reservoir, where fishery is constantly hold and a graziery of commercial fish species is concentrated (Fig. 1).

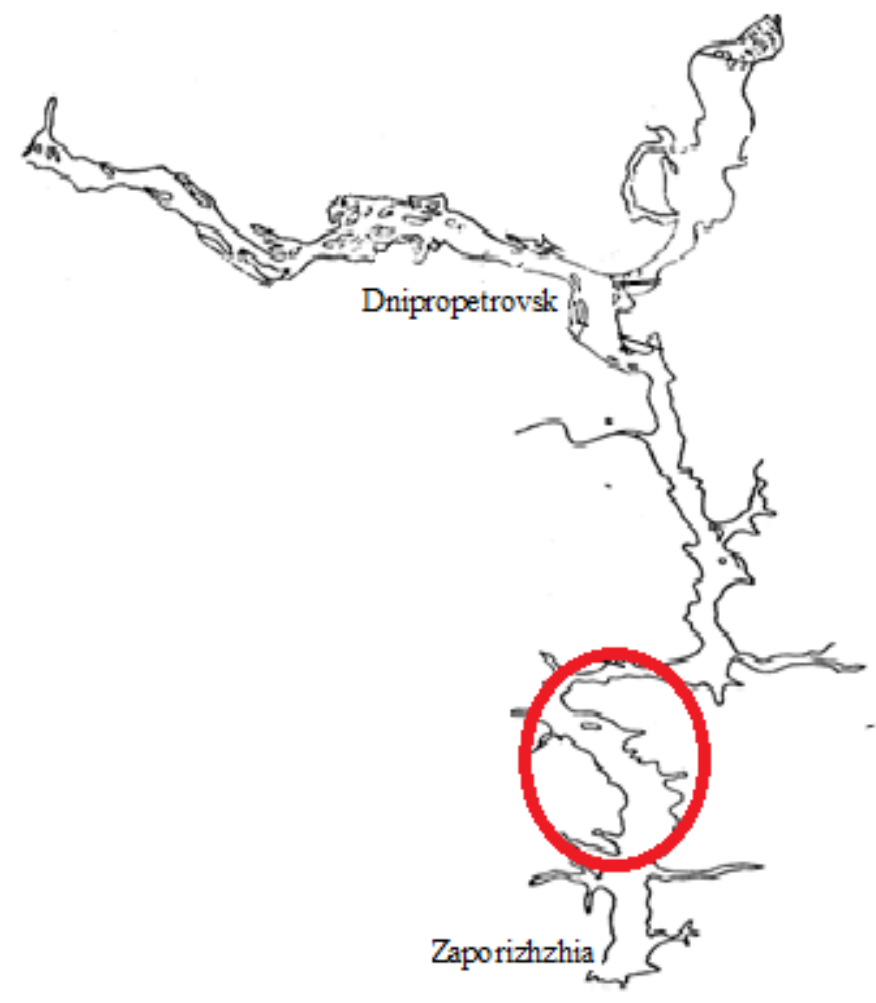

Fig. 1. The scheme of Zaporozhian reservoir and the site of samples location.

The underyearlings and 4-year prussian carp (Carassius gibelio Bloch, 1782) and common roach (Rutilus rutilus Linnaeus, 1758) species were the objects of this research. Material for the study was collected during the research catching in the summer-autumn period using gill nets. Blood was taken from the tail vein. Morphological studies were conducted on blood slides, which were stained by the method of Romanovsky-Himza. Blood slides were examined with the lens $40^{\mathrm{x}}$ increasing using a photomicrography with digital camera «Sciencelab T500 5.17 M». Herewith the following parameters were determined: a large longitudinal (D) and small cross (d) diameters of mature erythrocytes, erythrocyte area (S), an area of erythrocyte core (s), core-cytoplasmic ratio (s / $\mathrm{S})$, the percentage of mature erythrocytes (ME), the percentage of immature red blood cells (IE) and their forms. Cytometric measurements of erythrocyte indices were performed using the program ScienceLabView7. Numeric eccentricity of erythrocytes (E) was defined as the square root of the difference between one and the square of the ratio of small diameter to large diameter.

The content of heavy metals in water and fish bodies was determined by atomic absorption spectrophotometry. The concentration of cadmium, lead, copper, zinc, iron and manganese in the samples was determined by atomic absorption spectrophotometer S115-M1.

The data was analyzed as Mean \pm S.E.M. at reliability $95 \%$ and significant level of $\mathrm{P}<0.05$. In order to test the significant of the test, $\mathrm{t}$-test method was used. 


\section{RESULT AND DISCUSSION}

The lower section of the Zaporozhian Reservoir is characterized by satisfactory water exchange, located in the agricultural zone, the impact of toxic industrial waste is minimal. Water quality is mostly matched with the current fisheries regulations for carp fish. Comparing to Ukrainian standards only copper content exceeded the maximum allowable concentration for 7 times [25].

Investigation of heavy metals content in fish is an interesting field both in ecological and hygienic aspects. The information about the bioaccumulation of heavy metal in different ages of fish, living in similar environmental conditions is especially valuable.

Interspecies difference of heavy metals in underyearlings and 4-year researched fish was established. In the organism of mature roach individuals much less iron, zinc and lead by $79 \%, 71 \%$ and $82 \%$ was accumulated comparing with prussian carp (Fig. 2).

In young fish similar trend was found: roach underyearlings accumulate less iron and zinc by $59 \%$ and $54 \%$, respectively $(\mathrm{p} \leq 0.05)$. Interspecific differences in the accumulation of heavy metals may be related to feeding habits and the habitat of fish [26-28].

With the decrease in the concentration of heavy metals in the organisms of different age groups of carp fish from Zaporozhian Reservoir the following ranked series may be built:

$\mathrm{Zn}>\mathrm{Fe}>\mathrm{Mn}>\mathrm{Cu}>\mathrm{Pb}>\mathrm{Cd}$.

Thus, first of all items that are actively involved in the flow of physiological processes (respiration, hematopoiesis, etc.) accumulate in the organism rapidly, what is confirmed with researches by other authors [29].

Zinc actively accumulated in the body of young fish. The content of zinc in adult roach was lower by $62 \%$ comparing to fingerlings, and for the prussian carp - 39\% ( $\leq \leq 0.05)$. It happens due to the fact that zinc is a vital element. It is known that during the growth of fish the need in not only macro but also in micronutrients, including zinc increases. It is needed in a huge amount to form a skeleton, fins, and scales. As an activator of alkaline phosphatase it is required for the synthesis and activation of enzymes that contain zinc that provides the processes of tissue respiration, which are quite intense in the early ontogeny of fishes. This determines high accumulative ability of fish in the early stages of growth [30]. The same trend is observed in other accumulation of essential elements (iron, copper and manganese) by young prussian carp and roach from Zaporozhian Reservoir, but statistically there is not any significant difference between the different age groups of fish.

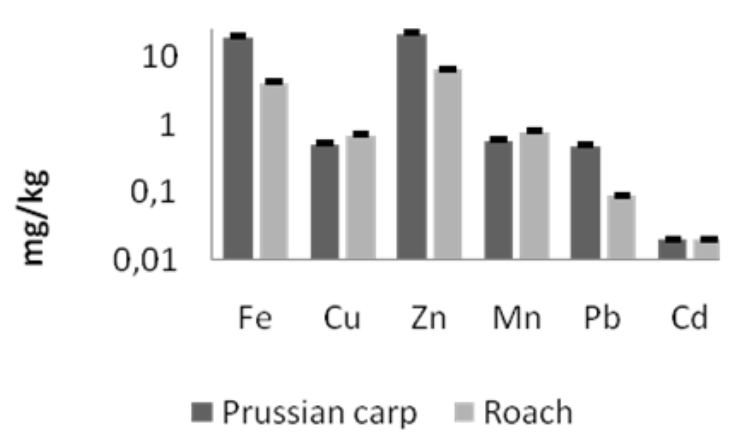

A

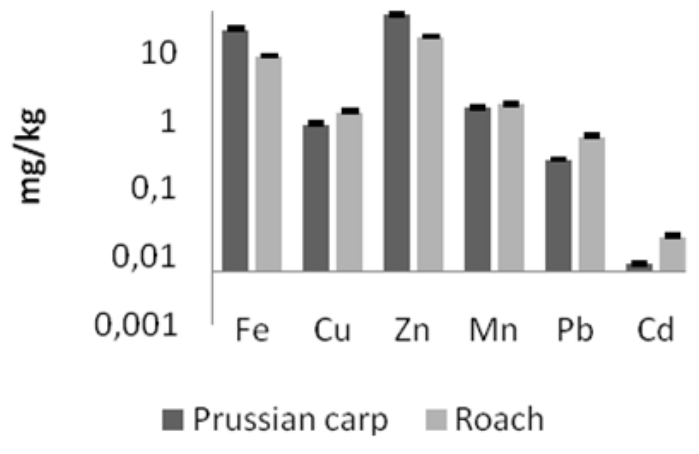

B

Fig. 2. The content of heavy metals in fish from Zaporozhian Reservoir: A - 4-year; B - underyearlings.

Cytometric characteristics of mature red blood cells in 4-year and underyearlings labels of researched carp fish had its own peculiarities. In young prussian carp and roach longitudinal diameter of red blood cells were 10-15\% lower than in adult fish, although the difference was not statistically expressed (Table. 1). The difference in small diameters of red blood cells varied in small limits. 
Table 1. Cytometric indicators of mature red blood cells of different ages prussian carp and roach in Zaporozhian Reservoir.

\begin{tabular}{|c|c|c|c|c|c|c|c|}
\hline \multirow[t]{2}{*}{$\begin{array}{l}\text { Species and } \\
\text { age of fish }\end{array}$} & \multicolumn{2}{|c|}{ Erythrocyte diameter, $\mu \mathrm{m}$} & \multicolumn{3}{|c|}{$\begin{array}{l}\text { The number of red blood cells } \\
\text { eccentricity, } \%\end{array}$} & \multirow[t]{2}{*}{$\begin{array}{l}\text { Area erythrocyte, } \\
\mu \mathrm{m}^{2}\end{array}$} & \multirow{2}{*}{$\begin{array}{l}\text { Area erythrocyte } \\
\text { nuclei, } \\
\mu \mathrm{m}^{2}\end{array}$} \\
\hline & $\mathrm{D}$ & $\mathrm{d}$ & $<0.65$ & $\begin{array}{ll}0.65 & - \\
0.75 & \end{array}$ & $>0.75$ & & \\
\hline $\begin{array}{l}\text { prussian } \\
\text { carp, } 0+\end{array}$ & $\begin{array}{l}12.27 \pm \\
0.47 \\
\end{array}$ & $8.52 \pm 0.5$ & 33 & 33 & 34 & $89.97 \pm 5.08^{*(* *)}$ & $18.43 \pm 1.83$ \\
\hline roach, $0+$ & $\begin{array}{l}11.19 \pm \\
0.29\end{array}$ & $8.14 \pm 0.12$ & 22 & 67 & 11 & $76.65 \pm 2.36^{(* *)}$ & $\begin{array}{l}17.43 \pm \\
0.75^{*}\end{array}$ \\
\hline $\begin{array}{l}\text { prussian } \\
\text { carp, 3+ }\end{array}$ & $\begin{array}{l}13.87 \pm \\
0.67\end{array}$ & $9.92 \pm 0.31$ & 33 & 44 & 23 & $109.02 \pm 3.85^{*(* * *)}$ & $19.44 \pm 0.62$ \\
\hline roach, $3+$ & $13.0 \pm 0.32$ & $7.99 \pm 0.3^{*}$ & 6 & 41 & 53 & $81.8 \pm 3.08^{(* * *)}$ & $13.97 \pm 0.64^{*}$ \\
\hline
\end{tabular}

* - The difference between the rates of different age groups of fish is possible, $\mathrm{p} \leq 0.05$.

The number of red blood cells eccentricity was not as depending on age as on specific features (Fig. 3). Thus, the prussian carp erythrocytes had varying degrees of elongation in approximately the same ratio. Oppositely, very elongated red blood cells prevailed in roach and with age significantly increased the number of eccentricity (from 11 to $53 \%$ ).

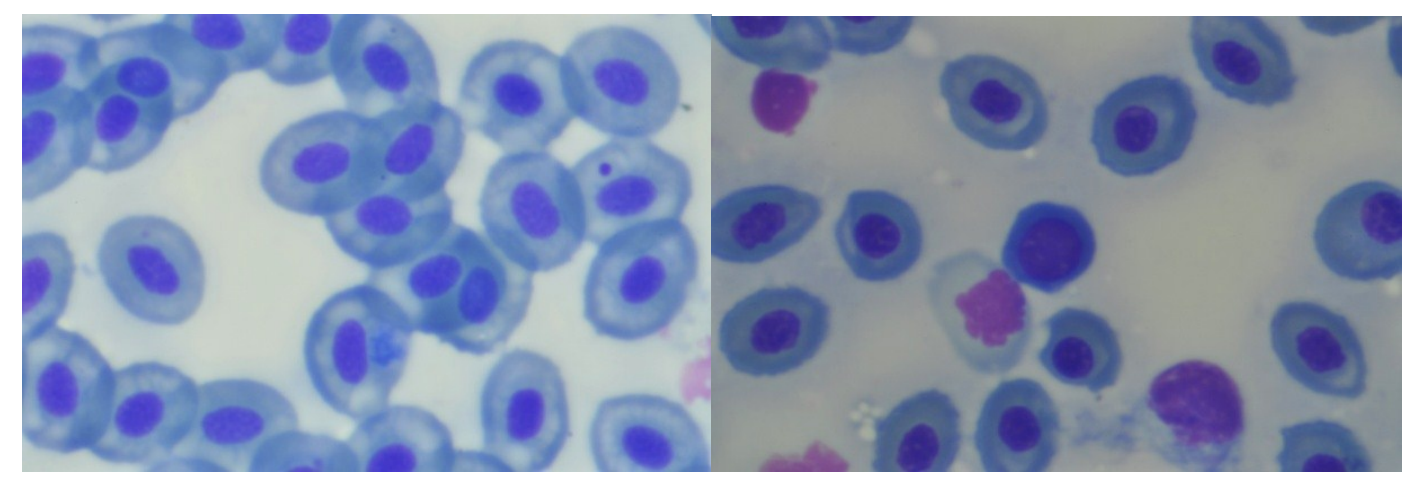

Fig. 3. Erythroid cells number of 4-year prussian carp (left) and roach (right).

Area of red blood cells in underyearlings was markedly lower than in older age groups of fish. In prussian carp this difference reached $18 \%$ and was statistically significant. In young roach area of erythrocytes was $8-10 \%$ lower than in adult fish $(\mathrm{p} \geq 0.05)$. In the literature there is no data on the size of red blood cells, depending on the age of prussian carp, but the minimum age group were the 2-year species [19]. Our research has showed that underyearlings red blood cells have significantly smaller footprint comparing to older groups. Obviously, the erythrocytes area begins to increase as the sexual maturation of fish and then remains relatively constant for this species of fish.

Erythrocyte core area was controversial with the of age fish. In the prussian carp core area slightly (5\%) increased, and in the roach, by contrast, has decreased, and the difference in this index between different age groups of roach reached $20 \%$ and was possible.

Any visible pathological phenomena in the red blood cells of both species were found. The relative amount of red blood cells with micronuclei in young and adult fish did not exceed $2 \%$.

Nuclear-cytoplasmic ratio calculations suggest that correlation of core area to the area of red blood cells of fish significantly reduced with age (Fig. 4). The difference in these rates in young and adult fish was $20-22 \%$. Thus, underyearlings erythrocytes quickly accumulate nuclear and more capable of mitotic division. Accordingly, we may assume that they are less actively performing specialized functions comparing to erythrocytes of older age groups of fish. Probable species differences of s / S indicator within similar age groups of fish were not detected. 


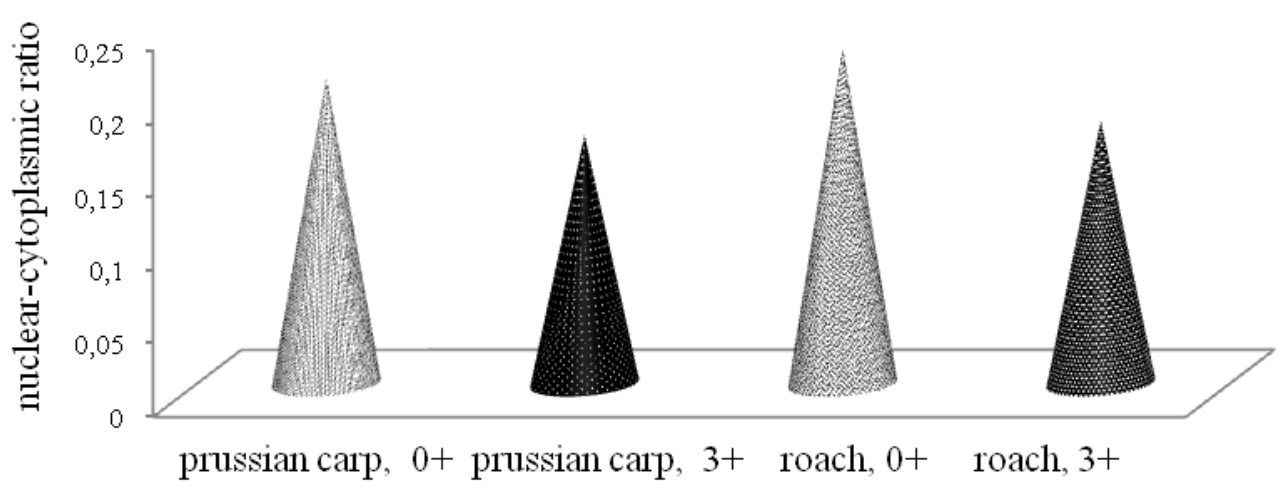

Fig. 4. Indicators of nuclear-cytoplasmic ratio of prussian carp and roach red blood cells of different age groups from Zaporozhian Reservoir.

The overall pattern of erythropoiesis in both species was the predominance of red mature percent for adult fish comparing to young fish. In prussian carp, these differences were $19 \%$ in roach $-11 \%$ (Fig. 5). Among the immature forms of erythrocytes (normoblasts of different maturity) in both species, regardless of age polychromatic normoblasts (PN) $5-9$ times comparing to basophilic normoblasts dominated $(\mathrm{BN})$.

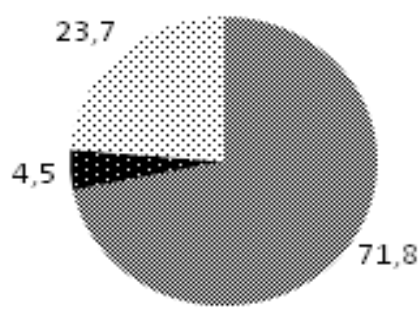

A

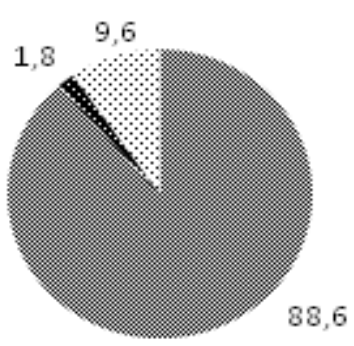

$\mathrm{C}$

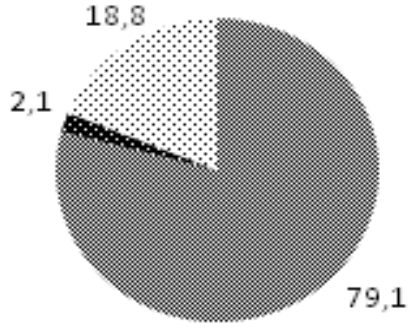

B

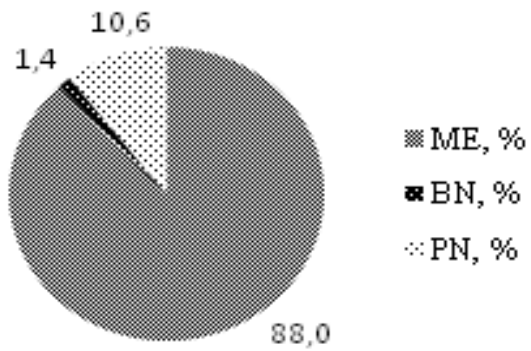

D

Fig. 5. Value of mature and immature forms of red blood cells in peripheral blood of fish:

$\mathrm{A}$ - underyearlings prussian carp, $\mathrm{B}$ - underyearlings roach $\mathrm{C}$ - 4-year prussian carp, D - 4-year roach.

There were also specific differences in terms of erythropoiesis in fish. Thus, roach underyearlings likely had more mature red blood cells, and therefore less immature forms of erythrocytes. Value IE: ME in roach underyearlings was 1: 4, in prussian carp underyearlings $1: 2.5$.

Value of certain normoblasts forms (BN: PN) in young prussian carp was equal to 1: 5 in roach $-1: 9$, the comparative number of polychromatic normoblasts in roach was almost twice as much. It was found that fish hemoglobin synthesis in erythroid cells begins with a phase of polychromatic normoblasts [19]. That is why we can assume that roach underyearlings erythropoiesis processes are more intense. 


\section{CONCLUSION}

The species differences of heavy metals in different age groups of prussian carp (Carassius gibelio B.) and common roach (Rutilus rutilus L.) were established, depending on their way of eating and habitat. First of all, in the organism of both species items that are actively involved in the flow of physiological processes in the body of fish (zinc and iron) accumulated.

Between the different age groups of one fish species statistically significant differences in bioaccumulation of zinc were established, which is the most needed in the early stages of ontogeny, that is why it was accumulated greater by fish fingerlings.

Results of cytometric research of erythropoiesis in roach and prussian carp different age groups showed that mature erythrocytes of fingerlings, unlike the red blood cells of older fish, have a smaller area but higher nuclear-cytoplasmic ratio, which indicates their ability to accumulate nuclear mass quickly and go to indirect cell division. Thus, underyearlings blood had almost twice as much immature forms of red blood cells than adult fish.

Concerning species differences of cytometric characteristics in mature red blood cells exaggeration of areas in red prussian carp, unlike roach, regardless of fish age was found. In addition, prussian carp erythrocytes took the form of varying degrees of elongation, while roach mostly had them very learned. It is considered that in the roach underyearlings process of erythropoiesis occurs more rapidly than in the prussian carp, as it can be indicated because of the predominance of the relative amount of functional developed normoblasts and mature red blood cells. Any abnormal red blood cells in both species were not detected.

Thus, our research showed that carp and roach fingerlings process of erythropoiesis and accumulation of essential elements, primarily - zinc, are more intense comparing to the older age groups of fish. These researches may be useful in determining the health condition of fish and reaction of the organism to the changes in the environment.

\section{References}

[1] V. Akhmetova, S. Vasina, Assessment of morphological and biochemical blood picture of carps of grown in LLC «FISH FARM» Ulyanovsk District of Ulyanovsk region, Bulletin of the Ulyanovsk State Agricultural Academy. 3(2015).

[2] G. Kumar B., B. Nandan S., Copper Toxicity: haematological and histopathological changes and prophylactic role of vitamin C in the fish, Anabas testudineus (Bloch, 1792), The Journal of Zoology Studies. 1(3)( 2014) 04-13.

[3] M. Vosyliené, A. Jankaite, Effect of heavy metal model mixture on rainbow trout biological parameters, EKOLOGIJA. 4(2006) 12-17.

[4] P. Golovin, Problems of fish stress in freshwater aquaculture: methods of diagnostics and correction, Collection of scientific papers, Diseases of fish, Sputnik, Moscow, 2004.

[5] J. Sharma, S. Langer, Effect of manganese on haematological parameters of fish, Garra gotyla gotyla, Journal of Entomology and Zoology Studies. 2 (3)(2014) 77-81.

[6] Kuramshina, E. Nurtdinova, Environmental and physiological characteristics of the fish in small rivers of the Southern Urals, Bulletin of the Orenburg State University. 4 (179) (2015) 240-243.

[7] J. A. Adakole, Changes in some haematological parameters of the African catfish (Clarias gariepinus) exposed to a metal finishing company effluent, Indian Journal of Science and Technology. Vol. 5, 4(2012) 2510-2514.

[8] M. Verholyas, N. Veyalkina, V. Goncharuk, Influence of copper ions on hematological and cytogenetic indicators of freshwater fish Carassius auratus gibelio, Cytology and Genetics. 2 (2010) 65-70. 
[9] F. Amineva, N. Kuramshina, Bioaccumulation of heavy metals $(\mathrm{Cu}, \mathrm{Cd}, \mathrm{Zn}, \mathrm{Pb})$ in muscles and organs of roach (Rutilus rutilus). In: Actual ecological problems: IV Int. Conf. Mater., Ufa. 2009, $7-8$.

[10]. R. Vinodhini, M. Narayanan, The impact of toxic heavy metals on the hematological parameters in common carp (Cyprinus carpio L.), Iran. J. Environ. Health. Sci. Eng. Vol. 6, 1(2009) 23-28.

[11] A. Mineev, Nonspecific reactions in fish from the reservoir of Middle and Lower Volga, The Samara Scientific Center of the Russian Academy of Sciences. Vol. 15, 3-7 (2013) 2301-2318.

[12] I. Velcheva, A. Arnaudov at al., A study on some physiological parameters of three hydrobiotic species under the influence of copper, In: Рељіс, V. \& Hadhiablahovic, S. (Eds.) Proceedings of the Symposium, II International Symposium of Ecologists of Montenegro. Kotor, 2006 155-160.

[13] L. Bugaev, O. Rudnitskaya, Use of hematological parameters to assess the functional status of producers walleye (Lucioperca lucioperca, L.), Proceedings of the international scientific conference "Problems of sustainable functioning of aquatic and terrestrial ecosystems." Rostov-onDon. 2006 50-52.

[14] T. Kuzina, Especially blood cytophysiological food fishes of the Volga-Caspian canal: Abstract, Astrakhan, ASU. 2011 5-24.

[15] T. Sharamok, N. Esipova, Influence of anthropogenic factors on hematological parameters of fish, Scientific notes Ternopil National Pedagogical University. 64(2015) 722-726.

[16] I. Parfenova, A. Soldatov, Functional morphology of circulating red blood cells bull-logs in experimental hypoxia, Marine Ecological Journal. 2 (2011) 59 - 67.

[17] N. Esipova, Y. Surova, Features of young red blood morphostructure cells of different species of young fish in hypoxic conditions, materials of VIII Ichthyological International Scientific Conference, Kherson, Green. $201571-74$.

[18] G. Serpunin, Hematological parameters adaptations fish, Monograph, Kaliningrad FGOU, VPO "KGTU", 2010.

[19] N. Ivanova, Atlas of fish blood, Moscow, 1983.

[20] A. Gayatri, M. Prafulla, The morphometrical characterisation of normal blood cells of two airbreathing fishes, Clarias batrachus and Anabas testudineus, International Research Journal of Biological Sciences, Vol. 3(11), 37(2014) 37-41.

[21] G. Rey Vrazquez, G.A. Guerrero, Characterization of blood cells and hematological parameters in Cichlasoma dimerus (Teleostei, Perciformes), Tissue and Cell 39(2007) 151-160.

[22] B. Nikolov, D. Boyadzieva-Doichinova, Parameters of the red blood cell count in three species of carp fishes, Bulgarian Journal of Agricultural Science. 16 (3)(2010) 307-310.

[23] O. V. Fedonenko, N. B. Esipova, T. S. Sharamok, T. V. Ananieva, V. O. Yakovenko, The current problems of hydrobiology: Zaporizke Reservoir, LIRA, Dnipropetrovsk, 2012.

[24] O. V. Fedonenko, T. S. Sharamok, Environmental assessment of key areas of Zaporizhzhya Reservoir fisheris (Ukraine), Ecological Bulletin of the North Caucasus. 11(2015) 45-50.

[25] Standart organization of Ukraine (SOU 05.01-37-385: 2006) Water fishery enterprises general requirements and standards.

[26] J. C. Akan, S. Mohmoud, B. S. Yikala at al., Bioaccumulation of some heavy metals in fish samples from river Benue in Vinikilang, Adamawa State, Nigeria, American Journal of Analytical Chemistry 3(2012) 727-736. 
[27] H. R. Voigt, Concentrations of mercury $(\mathrm{Hg})$ and cadmium $(\mathrm{Cd})$, and the condition of some Coastal Baltic fishes, Environmentalica Fennica, Vol. 21, 26(2004) 8-13.

[28] K. R. Campbell, Concentrations of heavy metals asso ciated with urban runoff in fish living in storm water treatment ponds, Archives of Environmental Contamination and Toxicology, Vol. 27, 3(1994) 352-356.

[29] I. Glazunova, Contents and distribution of heavy metals in organs and tissues of fish in $\mathrm{Ob}$, News of Altai State University 3(2007) 20 - 22.

[30] V. Romanenko, Fundamentals hydroecology, Kyiv, Oberegi, 2001. 